\title{
Covid Assossiated Invasive Fungal Sinusitis
}

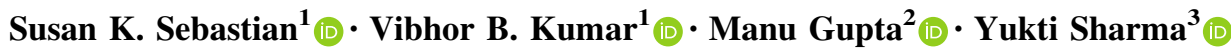

Received: 3 February 2021 / Accepted: 16 February 2021/Published online: 25 February 2021

(C) Association of Otolaryngologists of India 2021

\begin{abstract}
Acute invasive fungal sinusitis is an aggressive infection affecting immunocomprosmised patients and carries a high mortality. Patients with Covid-pneumonia are at an increased risk of developing invasive pulmonary fungal infections probably due to their reduced immunological competence. Here, we review three cases of Covidassociated invasive fungal sinusitis.
\end{abstract}

Keywords Covid-19 - Invasive fungal sinusitis .

Immunocompromised state

\section{Introduction}

Invasive fungal diseases are life-threatening infections affecting patients in immunocompromised state. It has been reported in the past that patients under intensive care due to influenza and respiratory viral infections including Covidpneumonia are at an increased risk of developing invasive

Susan K. Sebastian

drsusanjohn@ rediffmail.com; drsusanks@gmail.com

Vibhor B. Kumar

vibhormathu11@gmail.com

Manu Gupta

manugupta@live.com

Yukti Sharma

dryukti2006@yahoo.com

1 Department of ENT and Head and Neck Surgery, St. Stephen's Hospital, Tis Hazari, Delhi 110054, India

2 Department of Internal Medicine, St. Stephen's Hospital, Delhi 110054, India

3 Department of Microbiology, St. Stephen's Hospital, Delhi 110054, India pulmonary fungal infections probably due to their reduced immunological competence [1,2]. Here, we review three cases of Covid-associated invasive fungal sinusitis (CAIFS) highlighting the diagnostic and therapeutic challenges encountered. To our knowledge, Covid-19 assossiated acute invasive fungal rhinosinusitis has not been reported before.

\section{Case 1}

59 year man admitted in intensive care unit (ICU) with bilateral Covid-pneumonia with ARDS and on mechanical ventilation for seven days developed nasal blockage, facial and periorbital swelling and blackening of middle turbinate with thick dirty nasal discharge. He was a post coronary artery by-pass grafting patient with well controlled diabetes mellitus and was receiving insulin, broad spectrum intravenous antibiotics, dexamethasone, heparin and other supportive measures. Tissue from middle meatus revealed dual infection of aspergillus fumigatus and Rhizopus on potassium hydroxide $(\mathrm{KOH})$ test and fungal culture. Computed Tomography (CT) of paranasal sinuses revealed heterogenous opacification of bilateral maxillary, ethmoid, sphenoid and left frontal sinuses with involvement of left orbit (Fig. 1). After microbiological confirmation of CAIFS, liposomal Amphotericin B was given (total dose of $3050 \mathrm{mg}$ ). Subsequently he was continued on Voriconazole. Surgical debridement was done. Histopathology of sinus tissue confirmed the diagnosis of Mucormycosis. Progression of nasal disease halted, general condition improved and mechanical ventilation was discontinued. However, during the post-Covid recovery phase patient developed myocarditis with cardiac arrythmia and expired. 


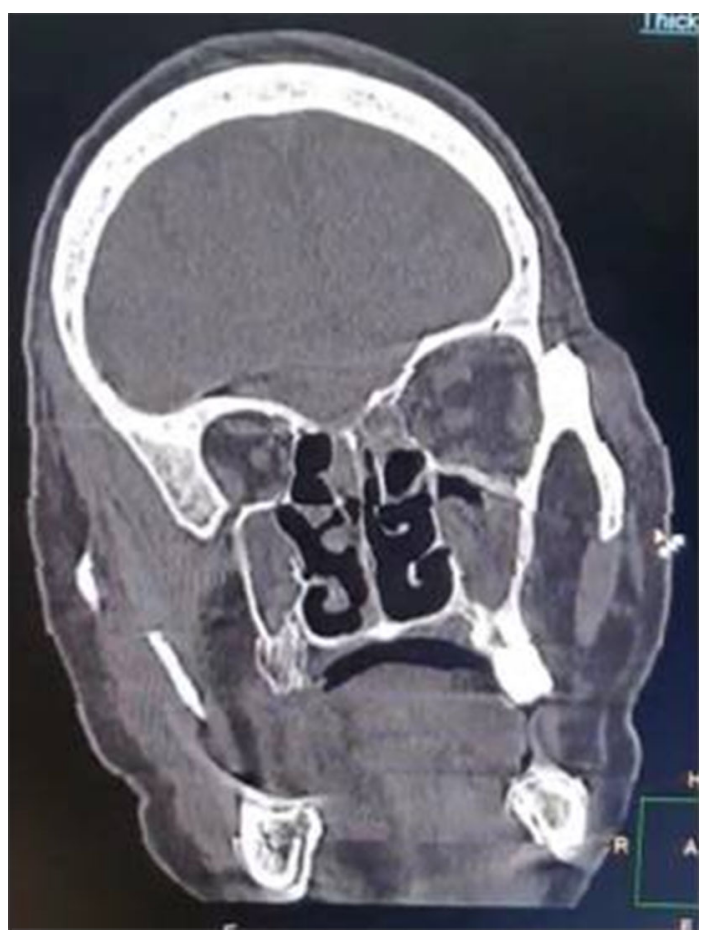

Fig. 1 Computed tomography paranasal sinuses. (Case-1)

\section{Case 2}

60 year man under ICU care for bilateral Covid pneumonia with ARDS, with diabetes mellitus and deranged kidney functions developed right eye pain, periorbital swelling, restricted eye movements and diminution of vision suggestive of orbital cellulitis with cavernous sinus thrombosis on the tenth day of admission. He was on insulin, broad spectrum intravenous antibiotics, dexamethasone and renal replacement therapy and required ventilatory and ionotropic support. Nasal endoscopy revealed blackening of the middle turbinate and the tissue from middle meatus revealed long aseptate, ribbon like hyphae suggestive of Zygomycosis on $\mathrm{KOH}$ test. Fungal culture confirmed the presence of Zygomycosis. Asymmetric soft tissue density in bilateral maxillary frontal, ethmoid and sphenoid sinuses were present on CT. He received a total dose of $850 \mathrm{mg}$ of liposomal amphotericin B but surgical debridement could not be carried out because of the poor general condition and persistent septicemic shock and the patient expired on the fourteenth day.

\section{Case 3}

64 year man admitted from the emergency department with bilateral Covid-pneumonia wth ARDS in an altered sensorium, renal failure and shock developed proptosis of right eye with periorbital bluish discoloration on the ninth day of admission. He was a known case of diabetes mellitus under control and peptic ulcer. He received insulin, broad spectrum antibiotics, hydrocortisone and mechanical ventilation and renal replacement therapy. Blackening of the lateral wall of nose with crusts and discharge was observed on nasal endoscopy. Computed tomography of paranasal sinuses revealed evidence of sinusitis involving right maxillary, bilateral ethmoid and sphenoid sinuses. $\mathrm{KOH}$ test of nasal tissue revealed fungus with broad asepate branching hyphae suggestive of Zygomycosis. Unfortunately he developed massive peptic ulcer bleed and went into irreversible shock and expired on the tenth day of hospital stay. Antifungal treatment could not be initiated in this patient.

\section{Discussion}

Patients with Covid-19 pneumonia requiring intensive care, share risk factors and underlying diseases that make them vulnerable to invasive fungal infections [3, 4]. Uncontrolled diabetes mellitus especially diabetic ketoacidosis is a common predisposing illness [4] for acute invasive fungal rhinisinusitis. Although patients in this series had history of diabetes mellitus, none was in diabetic ketoacidosis and diabetes was well controlled in two patients and hence diabetes mellitus may not have been a strong predisposing factor in them. Renal failure was present in two and one patient had coronary artery disease in the past. In addition, it is important to consider that the use of corticosteroids which are prescribed for Covid related complications may potentially reduce immune response [5]. In this series, the already compromised immunological competence of the patients due to Covid infection could have been further worsened by comorbidities and steroids [5]. All patients in this study developed features of acute invasive fungal rhinosinusitis 10-15 days after the onset of Covid-illness which probably coincides with the phase of sepsis-induced immune suppression [2].

Clinical characteristics, relevant investigations and treatment details are given in Table 1. Patients in this study presented with features of rapid tissue invasion through nasal mucosa, bone, neurovascular structures and surrounding organs. Radiology was nonspecific and the diagnosis of invasive fungus was made initially by bedside endoscopic evaluation and direct microscopic evidence of fungal hyphae using $10 \% \mathrm{KOH}$ test, which was later confirmed by mycology culture and histopathology which are reliable methods of diagnosis [4]. Histopathology revealed evidence of angio-invasion and lumenal thrombosis. Treatment of CAIFS consists of reversal of pre-disposing state, surgical debridement and antifungal therapy [4]. 
Table 1 Clinical profile

\begin{tabular}{|c|c|c|c|}
\hline & Case 1 & Case 2 & Case 3 \\
\hline Age/sex & $59 / \mathrm{M}$ & $60 / \mathrm{M}$ & $64 / \mathrm{M}$ \\
\hline Covid status & Covid-19 RTPCR + & Covid-19 RTPCR + & Covid-19RTPCR + \\
\hline $\begin{array}{l}\text { Clinical } \\
\text { presentation }\end{array}$ & $\begin{array}{l}\text { Covid-pneumonia with ARDS, } \\
\text { septicaemia }\end{array}$ & $\begin{array}{l}\text { Covid- pneumonia, uncontrolled diabetes } \\
\text { mellitus, deranged kidney functions }\end{array}$ & $\begin{array}{l}\text { Covid -pneumonia, septicemia, shock, } \\
\text { renal failure, altered sensorium }\end{array}$ \\
\hline $\begin{array}{l}\text { Features of } \\
\text { invasive } \\
\text { fungal } \\
\text { disease }\end{array}$ & $\begin{array}{l}\text { Facial swelling, proptosis, thick nasal } \\
\text { discharge, blackening of middle } \\
\text { turbinate (left side)-10 days after the } \\
\text { onset of Covid-illness }\end{array}$ & $\begin{array}{l}\text { Periorbital swelling, chemosis, restricted } \\
\text { eye movements, diminution of vision, } \\
\text { nasal discharge with blackening of } \\
\text { middle turbinate and septum (right } \\
\text { side)-15 days after the onset of illness }\end{array}$ & $\begin{array}{l}\text { Proptosis of eye with periorbital } \\
\text { discolouration, blackening of lateral } \\
\text { nasal wall with thick nasal discharge } \\
\text { (right side)—on the sixteenth day after } \\
\text { the onset of Covid illness } \\
\text { Developed massive hemetemesis on the } \\
\text { seventeenth day of illness }\end{array}$ \\
\hline Co-morbidities & $\begin{array}{l}\text { Diabetes mellitus, hypertension, } \\
\text { coronary artery disease (post-Coronary } \\
\text { Artery Bypass Grafting) }\end{array}$ & $\begin{array}{l}\text { Diabetes mellitus, deranged kidney } \\
\text { functions }\end{array}$ & $\begin{array}{l}\text { Diabetes mellitus, renal failure, peptic } \\
\text { ulcer }\end{array}$ \\
\hline $\begin{array}{l}\text { Predisposing } \\
\text { conditions } \\
\text { for invasive } \\
\text { fungal } \\
\text { infection }\end{array}$ & $\begin{array}{l}\text { COVID- pneumonia with ARDS, } \\
\text { diabetes mellitus, steroid therapy }\end{array}$ & $\begin{array}{l}\text { COVID-pneumonia with ARDS diabetes } \\
\text { mellitus, renal failure steroid therapy }\end{array}$ & $\begin{array}{l}\text { COVID- pneumonia with ARDS, } \\
\text { diabetes mellitus, steroid therapy }\end{array}$ \\
\hline $\begin{array}{l}\text { Radiology } \\
\text { Computed } \\
\text { tomography- } \\
\text { Thorax }\end{array}$ & $\begin{array}{l}\text { Bilateral non-lobar distribution of ground } \\
\text { glass opacities with septal thickening } \\
\text { involving lung parenchyma. Fibro- } \\
\text { parenchymal scarring causing } \\
\text { architectural distortion and } \\
\text { bronchiectasis changes in left lobe }\end{array}$ & $\begin{array}{l}\text { Bilateral peripheral distribution of } \\
\text { ground glass opacities with septal } \\
\text { thickening involving lung } \\
\text { parenchyma. Few subpleural fibrotic } \\
\text { bands in left lower lobe. Minimal } \\
\text { pericardial effusion }\end{array}$ & $\begin{array}{l}\text { Non lobar distribution of ground glass } \\
\text { opacities with septal thickening } \\
\text { involving bilateral lung parenchyma }\end{array}$ \\
\hline $\begin{array}{l}\text { Computed } \\
\text { tomography- } \\
\text { Paranasal } \\
\text { sinuses }\end{array}$ & $\begin{array}{l}\text { Heterogeneous opacification of bilateral } \\
\text { maxillary ethmoid, sphenoid and left } \\
\text { frontal sinuses. Osteo-meatal complex, } \\
\text { frontal recess. spheno-ethmoidal } \\
\text { recess occluded on left side } \\
\text { Proptosis of left eye with bulky left } \\
\text { inferior rectus muscle with retro-conal } \\
\text { fat stranding }\end{array}$ & $\begin{array}{l}\text { Soft tissue density in bilateral maxillary, } \\
\text { ethmoid, frontal and sphenoid sinuses } \\
\text { suggestive of pan sinusitis }\end{array}$ & $\begin{array}{l}\text { Soft tissue density in right maxillary, } \\
\text { sphenoid and bilateral ethmoidal } \\
\text { sinuses }\end{array}$ \\
\hline $\begin{array}{l}\text { Microbiology } \\
\text { Potassium } \\
\text { hydroxide } \\
\text { test for } \\
\text { fungus }\end{array}$ & $\begin{array}{l}\text { Long hyaline, septate branching hyphae } \\
\text { and aseptate hyphae suggestive of dual } \\
\text { infection with Aspergillus and } \\
\text { mucormycosis seen }\end{array}$ & $\begin{array}{l}\text { Long aseptate, irregular, ribbonlike } \\
\text { hyphae seen suggestiveof zygomycosis }\end{array}$ & $\begin{array}{l}\text { Broad septate hyphae seen in abundance } \\
\text { suggestive of mucormycosis }\end{array}$ \\
\hline Fungal culture & $\begin{array}{l}\text { Aspergillus fumigatus and Rhizopus } \\
\text { grown }\end{array}$ & Zygomycosis grow & Not done \\
\hline Histopathology & $\begin{array}{l}\text { Invasive Fungal sinusitis-consistent with } \\
\text { mucormycosis }\end{array}$ & Not done & Not done \\
\hline Treatment & $\begin{array}{l}\text { Mechanical ventilation, vasopressors, } \\
\text { renal replacement therapy } \\
\text { Broad spectrum antibiotics, steroids, } \\
\text { insulin therapy }\end{array}$ & $\begin{array}{l}\text { Mechanical } \\
\text { ventilation,vasopressors,renal } \\
\text { replacement therapy } \\
\text { Broad spectrum antibiotics, steroids, } \\
\text { insulin therapy }\end{array}$ & $\begin{array}{l}\text { Mechanical ventilation,vasopressors } \\
\text { renal replacement therapy } \\
\text { Broad spectrum antibiotics, steroids, } \\
\text { insulin therapy }\end{array}$ \\
\hline $\begin{array}{l}\text { Antifungal } \\
\text { treatment: } \\
\text { Medical } \\
\text { treatment }\end{array}$ & $\begin{array}{l}\text { Liposomal Amphotericin B, } \\
\text { Voriconazole }\end{array}$ & Liposomal Amphotericin B & Antifungal agents not given \\
\hline $\begin{array}{l}\text { Surgical } \\
\text { Debridement }\end{array}$ & Endoscopic debridement & Not done & Not done \\
\hline Outcome & Expired & Expired & Expired \\
\hline
\end{tabular}


CAIFS is associated with rapid clinical worsening compromising aggressive anti-fungal treatment at times.

\section{Conclusion}

COVID-19 infection is probably a predisposing factor for acute invasive fungal rhinosinusitis and is assossiated with a high mortality.

Author Contributions SKS: Substantial contributions to the conception of the work, the acquisition, analysis, interpretation critical analysis of data and drafting the work. Approved the version to be published and agreed to be accountable for all aspects of the work. VBK: Substantial contributions to the acquisition, analysis, interpretation and revision of data Approved the version to be published and agreed to be accountable for all aspects of the work. MG: Substantial contributions to the conception of the work, interpretation and analysis of data. Approved the version to be published and agreed to be accountable for all aspects of the work. YS: Substantial contributions to the acquisition, analysis, interpretation and analysis of data. Approved the version to be published and agreed to be accountable for all aspects of the work.

Funding We have not received any funding or financial support from any source for the conduct of this study. The authors have no relevant financial or non-financial interests to disclose. All authors certify that they have no affiliations with or involvement in any organization or entity with any financial interest or non-financial interest in the subject matter or materials discussed in this manuscript. The authors have no financial or proprietary interests in any material discussed in this article.

\section{Compliance with Ethical Standards}

Conflict of interest Authors declare no conflict of interest.

Ethical Approval Institutional Ethics Committee clearence obtained. No: SSHEC/R0179. This study is a retrospective analysis. Hence it does not have a CTRI Number. All procedures performed in this study are in accordance with the ethical standards of the institutional research committee and with the 1964 Helsinki declaration and its amendments. Informed consent has been waived by the ethics committee.

\section{References}

1. Schauwvlieghe AFAD, Rijnders BJA, Philips N et al (2018) Invasive aspergillosis in patients admitted to the intensive care unit with severe influenza: a retrospective cohort study. Lancet Respir Med 6(10):782-792

2. Hotchkiss RS, Monneret G, Payen D (2013) Sepsis-induced immune-suppression: from cellular dysfunctions to immunotherapy. Nat Rev Immunol 13:862-874

3. Gangneux JP, Bougnoux ME, Zahar JR et al (2020) Invasive fungal diseases during COVID-19: We should be prepared. J de MycologieMe'dicale 30:100971

4. Deutsch PG, Whittaker J, Prasad S (2019) Invasive and noninvasive fungal rhinosinusitis-a review and update of the evidence. Medicine 55:319. https://doi.org/10.3390/medicina 5507031

5. Lai C-C, Yu W-L (2020) COVID-19 associated with pulmonary aspergillosis: a literature review. J Microbiol Immunol Infect $54: 46-53$

Publisher's Note Springer Nature remains neutral with regard to jurisdictional claims in published maps and institutional affiliations. 